Brit. J. vener. Dis. (1960), 36, 181.

\title{
A STUDY OF THE AETIOLOGY OF NON-GONOCOCCAL URETHRITIS AND REITER'S DISEASE*
}

\author{
BY \\ G. W. CSONKA \\ St. Mary's Hospital, London \\ AND \\ G. FURNESS $\uparrow$ \\ Wright-Fleming Institute, London
}

Ford $(1956,1958)$ inoculated cultures of Hela, human amnion, and conjunctival cells with material from patients with non-gonococcal urethritis (N.G.U.) and examined the cells for cytopathogenicity. He found some cellular degeneration but attributed this to the presence of pleuropneumonialike organisms (PPLO) rather than virus.

Inclusion bodies have been demonstrated in urethral scrapings from some cases of N.G.U. and Reiter's disease (Harkness, 1950; Durel, RoironRatner, and Borel, 1951; Siboulet, 1952; Thygeson, 1954; Brisou, 1954; Masbernard, 1959; and several others). Viruses may produce inclusion bodies without gross degeneration in the cell monolayer, as

* Received for publication March 2, 1960.

† Present address: The Lister Institute, London. for instance in the psittacosis-lymphogranuloma group of viruses, some of which can cause venereal disease. Therefore, in the present study, chickembryo cell cultures were inoculated with material from patients having the symptoms of N.G.U. and Reiter's disease and the monolayers of cells were examined not only for gross degeneration but also for inclusion bodies.

\section{Material and Methods}

Seventeen untreated male patients attending the Special Clinic of St. Mary's Hospital with pronounced early symptoms of N.G.U. were selected as suitable for investigation; in addition, three patients having N.G.U. and early Reiter's disease were investigated. Some clinical data of these twenty cases are given in Table I.

TABLE I

CLINICAL HISTORY OF PATIENTS WITH N.G.U. AND REITER'S DISEASE

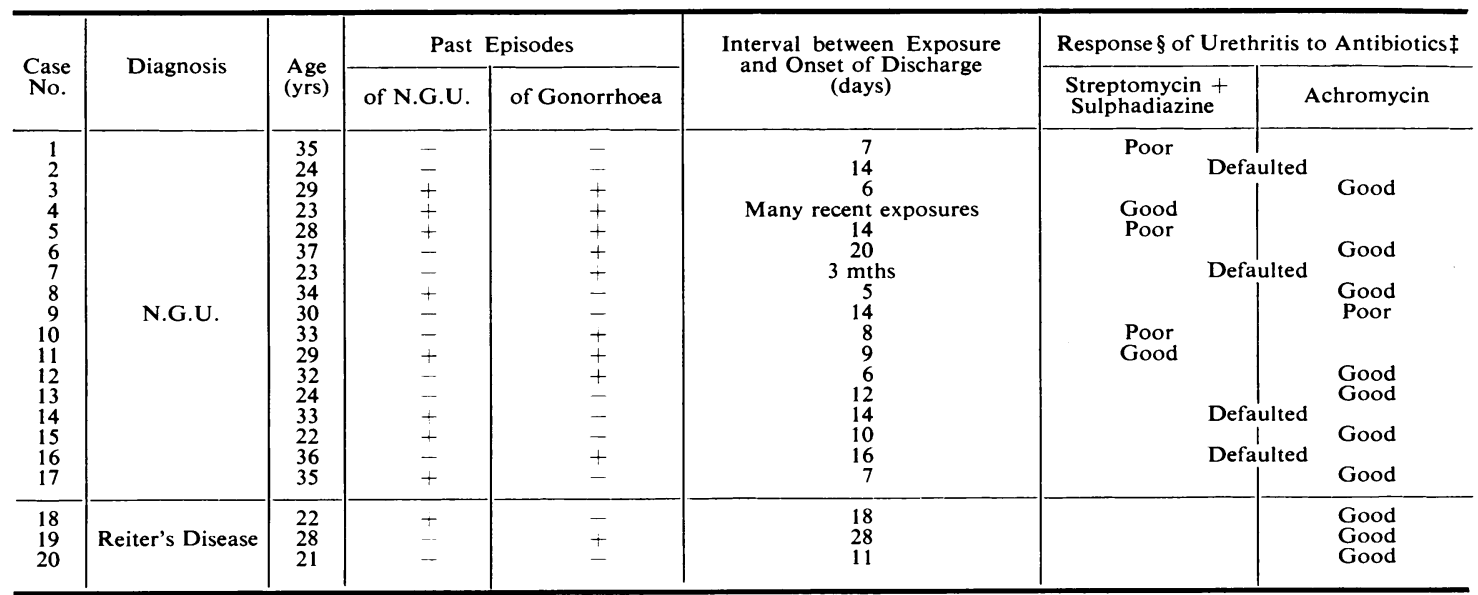

‡ Dosage Scheme: Streptomycin $1 \mathrm{~g} .+$ Sulphadiazine $1 \mathrm{~g}$., four times daily for 5 days. Achromycin $0 \cdot 25 \mathrm{~g}$. four times daily for 5 days. $\S$ Clinical response was assessed one week after the start of treatment. The response was recorded as good when there was no urethral discharge. 
After the meatus had been cleansed with saline, discharge was obtained from within the urethra by means of a platinum loop. Cell cultures not more than 4 days old were inoculated for the isolation of viruses, and broth and special nutrient agar plates were inoculated for the isolation of PPLO. In addition, material from the inflamed conjunctiva and mouth of a patient with Reiter's disease was similarly cultured. Dr. E. Klieneberger-Nobel and Dr. R. M. Lemcke examined these cultures and the supernatant medium of the final passage of the cell cultures for the presence of PPLO.

Chick-embryo Cell Cultures.-9-day embryos were decapitated, chopped with scissors, and stirred with trypsin solution for a few minutes to suspend the blood. After the tissue had settled, the supernatant was decanted and $250 \mathrm{ml}$. trypsin solution added to the mince from twelve embryos. The tissue suspension was trypsinized for $30 \mathrm{~min}$. at room temperature in a Rappaport flask on a magnetic stirrer. The suspension of cells was filtered through gauze and centrifuged at 1,000 r.p.m. for 10 min., and the supernatant was decanted. The packed cells were resuspended in Medium 199 to a density of $2 \times 10^{6} / \mathrm{ml}$. and dispensed in amounts of $3 \mathrm{ml}$. in screw-capped cell culture tubes containing a coverslip approximately $5 / 24 \times 1 \frac{1}{2}$ in. A monolayer was obtained after overnight incubation at $37^{\circ} \mathrm{C}$. Thereafter the cell cultures were maintained at room temperature until inoculated. The inoculated cell cultures were incubated at $37^{\circ} \mathrm{C}$. and examined daily for cytopathic effect. As the monolayer tended to leave the glass after 4 to 5 days at $37^{\circ} \mathrm{C}$., the coverslips were removed aseptically between the second and fifth day and stained for inclusion bodies. The cells remaining in the tubes were then resuspended and $0.25 \mathrm{ml}$. of this suspension was re-inoculated into 24-hrs cell cultures or else the tubes were kept at $4^{\circ} \mathrm{C}$. until fresh cultures were available.

Media and Solutions.-The following solutions containing 100 units $/ \mathrm{ml}$. penicillin and $100 \mu \mathrm{g} . / \mathrm{ml}$. streptomycin were used in the preparation of chickembryo monolayers:

Medium 199 (Glaxo Laboratories Ltd.) containing 10 per cent. calf serum inactivated at $56^{\circ} \mathrm{C}$. for $30 \mathrm{~min}$.

Trypsin (Difco Laboratories, Inc.) 0.25 per cent. concentration in phosphate buffer solution.

The medium used for the cultivation of PPLO has been described elsewhere (Klieneberger-Nobel, 1959a).
Stains.-When un-inoculated chick embryo cell cultures were stained with Giemsa, pink bodies were found which could be confused with an unknown virus inclusion body. Macchiavello's stain did not manifest these bodies and in consequence this method of staining was used. After fixing with a mixture of equal parts of ether and alcohol, the films were washed and stained with 0.25 per cent. basic fuchsin (pH 7.3) for $5 \mathrm{~min}$. They were again washed, decolourized with 0.5 per cent. citric acid, washed, and counter-stained with 0.5 per cent. methylene blue. Buffer pH $6 \cdot 8$ was used throughout for washing.

\section{Results}

If there was sufficient discharge, the PPLO media and up to three cell cultures were inoculated from each patient. The relevant details about the number of passages and the presence of PPLO are given in Table II (opposite).

There was no evidence of deterioration in cell cultures inoculated from patients suffering from N.G.U. After not less than two passages, cell cultures containing coverslips were inoculated and the coverslips were stained for inclusion bodies. No inclusion bodies were found; however, PPLO were grown in two out of the seventeen cases of N.G.U.

Of the three patients suffering from Reiter's disease, one was admitted to the hospital and a more detailed investigation was made. The patient, a man aged 21, developed a urethral discharge in June, 1959, 2 months after his first intercourse with a stranger; 8 days after the onset of the urethritis, balanitis developed, and was followed a day or two later by conjunctivitis and painful swelling of the right knee and the left temporomandibular joint. A week later keratoderma appeared on the buttocks and abdomen. The erythrocyte sedimentation rate was $136 \mathrm{~mm}$./hr (Westergren) and the serum electrophoretic protein pattern showed a conspicuous increase of alpha $_{1}$ and alpha $a_{2}$ globulins. $X$-ray films of the sacro-iliac joints showed loss of definition with marginal porotic and sclerotic changes. All these features may be found in the more severe types of Reiter's disease. Urethral secretions contained numerous pus cells and appeared to be abacterial. Routine cultures were sterile. However, in the special media used for the cultivation of PPLO, this organism grew abundantly. Some of the chick-embryo cell cultures inoculated with urethral discharge from this patient deteriorated. The cytopathic effect occurred sporadically. When they were 
TABLE II

SUMMARY OF LABORATORY INVESTIGATIONS OF PATIENTS WITH N.G.U. AND REITER'S DISEASE

\begin{tabular}{|c|c|c|c|c|c|c|c|}
\hline \multirow[b]{2}{*}{$\begin{array}{l}\text { Case } \\
\text { No. }\end{array}$} & \multirow[b]{2}{*}{ Diagnosis } & \multirow{2}{*}{$\begin{array}{c}\text { Interval between } \\
\text { Onset of } \\
\text { Discharge and } \\
\text { Taking of } \\
\text { Specimen } \\
\text { (days) }\end{array}$} & \multirow{2}{*}{$\begin{array}{l}\text { No. of Duplicate } \\
\text { Specimens taken } \\
\text { for Cell Culture }\end{array}$} & \multirow{2}{*}{$\begin{array}{c}\text { No. of Serial } \\
\text { Passages } \\
\text { examined for Cy- } \\
\text { topathogenicity }\end{array}$} & \multirow{2}{*}{$\begin{array}{c}\text { Serial Passage } \\
\text { examined for } \\
\text { Inclusion Bodies }\end{array}$} & \multicolumn{2}{|c|}{ PPLO in } \\
\hline & & & & & & $\begin{array}{c}\text { Original } \\
\text { Inoculum }\end{array}$ & $\begin{array}{c}\text { Chick-embryo } \\
\text { Cultures* }\end{array}$ \\
\hline $\begin{array}{r}1 \\
2 \\
3 \\
4 \\
5 \\
6 \\
7 \\
8 \\
9 \\
10 \\
11 \\
12 \\
13 \\
14 \\
15 \\
16 \\
17\end{array}$ & N.G.U. & $\begin{array}{r}3 \\
2 \\
4 \\
4 \\
3 \\
18 \\
3 \\
1 \\
3 \\
5 \\
2 \\
1 \\
3 \\
9 \\
1 \\
1 \\
3\end{array}$ & $\begin{array}{l}2 \\
2 \\
1 \\
2 \\
1 \\
1 \\
1 \\
1 \\
1 \\
3 \\
3 \\
2 \\
2 \\
2 \\
1 \\
2 \\
2\end{array}$ & $\begin{array}{l}4 \\
6 \\
6 \\
5 \\
6 \\
5 \\
6 \\
6 \\
5 \\
6 \\
5 \\
4 \\
5 \\
5 \\
5 \\
4 \\
4 \\
4\end{array}$ & $\begin{array}{l}2,3,4 \\
3,4,5,6 \\
2,3,6 \\
3,4,5 \\
4,5,6 \\
3,5 \\
4,6 \\
3,4,5 \\
4,5,6 \\
3,4,5 \\
2,3,4 \\
3,4,5 \\
2,4,5 \\
3,4,5 \\
2,3,4 \\
2,3,4 \\
2,3,4\end{array}$ & $\begin{array}{l}\overline{+} \\
- \\
- \\
- \\
+ \\
- \\
- \\
= \\
- \\
- \\
- \\
- \\
-\end{array}$ & $\begin{array}{l}\overline{+} \\
- \\
- \\
\overline{-} \\
\overline{-} \\
- \\
- \\
- \\
- \\
- \\
- \\
- \\
-\end{array}$ \\
\hline $\begin{array}{l}18 \\
19 \\
20\end{array}$ & Reiter's Disease & $\begin{array}{l}14 \\
21 \\
10\end{array}$ & $\begin{array}{l}1 \\
2 \\
2\end{array}$ & $\begin{array}{l}5 \\
7 \\
9\end{array}$ & $\begin{array}{l}3,4,5 \\
5,6,7 \\
5,6,7,8,9\end{array}$ & $\overline{-}$ & $\overline{-}$ \\
\hline
\end{tabular}

${ }^{*}$ Final passage examined.

examined for PPLO, all were found to be highly contaminated. In contrast, those cultures inoculated from the conjunctiva and mouth were not infected with PPLO and did not show any cytopathic effect. It was therefore considered that these changes could not be attributed to a viral aetiology. The serum of this patient was tested at intervals for complementfixing antibodies against PPLO and gave a rising titre as the disease progressed (Table III).
It has been reported that very occasionally chickembryo cell cultures may be infected with PPLO originally derived from the hen (Van Herick and Eaton, 1945). In the present series several hundred chick embryos were used without any evidence of contamination from this source. Moreover, the PPLO isolated from cell culture tubes were serologically identified as belonging to the human genital type.

TABLE III

CELL CULTURE STUDIES AND INVESTIGATION FOR PPLO IN ONE PATIENT WITH REITER'S DISEASE (CASE 20)

\begin{tabular}{|c|c|c|c|c|c|c|c|c|}
\hline \multirow[b]{2}{*}{ Date } & \multirow[b]{2}{*}{ Remarks } & \multirow{2}{*}{$\begin{array}{c}\text { Erythrocyte } \\
\text { Sedimenta- } \\
\text { tion Rate } \\
\text { (Westergren } \\
\mathrm{mm} . / \mathrm{hr} \text { ) }\end{array}$} & \multirow{2}{*}{$\begin{array}{c}\text { No. of } \\
\text { Duplicate } \\
\text { Specimens } \\
\text { taken for } \\
\text { Cell Culture }\end{array}$} & \multirow{2}{*}{$\begin{array}{c}\text { No. of Serial } \\
\text { Passages } \\
\text { examined for } \\
\begin{array}{c}\text { Cytopatho- } \\
\text { genicity }\end{array}\end{array}$} & \multirow{2}{*}{$\begin{array}{c}\text { Serial } \\
\text { Passages } \\
\text { examined for } \\
\text { Inclusion } \\
\text { Bodies* }\end{array}$} & \multicolumn{3}{|c|}{ PPLO } \\
\hline & & & & & & $\begin{array}{c}\text { In } \\
\text { Urethral } \\
\text { Discharget }\end{array}$ & $\begin{array}{c}\text { Serum } \\
\text { Complement- } \\
\text { fixation } \\
\text { Test }\end{array}$ & $\begin{array}{c}\text { In final } \\
\text { Passages of } \\
\text { Cell Culture }\end{array}$ \\
\hline $\begin{array}{l}19.6 .59 \\
22.6 .59 \\
23.6 .59\end{array}$ & $\begin{array}{l}\text { Untreated Febrile } \\
\qquad 100-101^{\circ} \mathrm{F} . \ldots\end{array}$ & $\begin{array}{r}12 \\
127\end{array}$ & $\begin{array}{l}3 \\
2 \\
3\end{array}$ & $\begin{array}{l}9 \\
7 \\
3\end{array}$ & $\begin{array}{c}5,6,7,8,9 \\
6,7 \\
3\end{array}$ & ++ & - & ++ \\
\hline $\begin{array}{l}25.6 .59 \\
30.6 .59 \\
7.7 .59 \\
9.7 .59 \\
14.7 .59 \\
17.7 .59 \\
24.7 .59 \\
30.7 .59 \\
14.8 .59 \\
17.9 .59\end{array}$ & 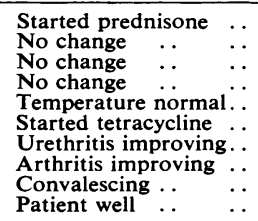 & $\begin{array}{r}136 \\
120 \\
132 \\
115 \\
142 \\
90 \\
126 \\
10\end{array}$ & $\begin{array}{l}3 \\
\mathbf{3}\end{array}$ & $\begin{array}{l}3 \\
3\end{array}$ & $\begin{array}{l}3 \\
3\end{array}$ & $\begin{array}{c}- \\
++ \\
- \\
-\end{array}$ & $\begin{array}{c}- \\
- \\
1 / 40-1 / 80 \\
1 / 80 \\
1 / 40 \\
1 / 40-1 / 80\end{array}$ & \\
\hline
\end{tabular}

* Only cultures without degeneration could be stained for inclusion bodies.

† Specimens from the inflamed conjunctiva and mouth ulcers were negative for PPLO and did not give rise to degeneration of cells. 


\section{Discussion}

PPLO is found in the urethra and may therefore be expected as a contaminant in a proportion of the samples obtained when this source is being investigated for the presence of viruses. Although PPLO has been isolated from cell lines without any signs of cytopathogenicity (Collier, 1957), it was considered by Ford (1958) that PPLO from the urogenital tract may have been responsible for the cell deterioration noted in his investigation of N.G.U. Our results suggest that under certain conditions these organisms are cytopathic. We found that cell deterioration occurred sporadically and was not seen in every passage as might be expected with a virus adapted for growth in a monolayer. Monolayers inoculated from other patients free from PPLO showed no deterioration, which suggests that the effect was not due to spontaneous degeneration of the monolayers. However, the factors which enabled these organisms to destroy the cells are unknown.

As PPLO is believed to be more often present in the diseased than in the normal genito-urinary tract (Dienes and Edsall, 1937: Harkness and HendersonBegg, 1948; Melén and Linnros, 1952; Shepard, 1954; Klieneberger-Nobel, 1959b), the rejection of patients harbouring these organisms might well exclude the most promising cases for investigation of an unknown aetiological agent.

From the results it appears that the presence of PPLO in the cultures may be ignored until such time as either gross degeneration of cell cultures or inclusion bodies are seen in serial passage. Only then would it be necessary to exclude PPLO as the causative agent. The results do not support a virus aetiology; neither can the conditions be accounted for by PPLO, as the organism was only isolated from three out of twenty patients examined. There is always the possibility that cultural conditions, such as temperature and length of incubation, were suboptimal. However, where viruses are known to produce inclusion bodies in cell culture, they can usually be observed between the third and fifth day of incubation at $33-37^{\circ} \mathrm{C}$. It seems more likely that, if viruses are responsible for the condition of these patients, chick-embryo cell cultures are not suitable for their isolation.

\section{Summary}

The urethral discharge from seventeen patients with non-gonococcal urethritis and three with Reiter's disease was investigated in chick-embryo cell cultures for the production of cytopathic effects and inclusion bodies. No changes were observed in the cultures from the cases of non-gonococcal urethritis. In one case of Reiter's disease, degeneration occurred but could not be continuously passaged. From this patient PPLO grew abundantly, and his serum contained complement-fixing antibodies against this organism. It is thought likely that the cytopathic effect in the cultures of his urethral discharge was due to the PPLO known to be present in it and not to virus. There was no evidence of contamination of the chick-embryo cell cultures by PPLO originating in the egg.

This work was carried out under the aegis of the Medical Research Council Working Party on Non-Specific Urethritis, with the aid of a grant from the U.S. Public Health Service. We wish to thank Professor A. A. Miles and Mr. A. J. King for their interest and advice, Dr. F. J. G. Jefferiss and Dr. R. R. Willcox for their permission to investigate the patients under their care, and Dr. E. Klieneberger-Nobel and Dr. R. M. Lemcke for their work on PPLO. We are grateful to Miss Margaret Ham for her excellent technical advice.

\section{REFERENCES}

Brisou, J. (1954). Paper read at the International Symposium on Non-Gonococcal Urethritis, Monaco. WHO Publication VDT/125.

Collier, L. H. (1957). Nature (Lond.), 180, 757.

Dienes, L., and Edsall, G. (1937). Proc. Soc. exp. Biol. (N. Y.), 36,740.

Durel, P., Roiron-Ratner, V., and Borel, L.-J. (1951). Presse méd., 59, 789.

Ford, D. K. (1956). Brit. J. vener. Dis., 32, 184.

- (1958). Ibid., 34, 53.

Harkness, A. H. (1950). "Non-gonococcal Urethritis", p. 68. Livingstone, Edinburgh.

— and Henderson-Begg, A. (1948). Brit. J. vener. Dis., 24, 50.

Klieneberger-Nobel, E. (1959a). Brit. med. J., 1, 19.

_- (1959b). Brit. J. vener. Dis., 35, 20.

Masbernard, A. (1959). Rev. Rhum., 26, 21.

Melén, B., and Linnros, B. (1952). Acta derm. venereol. (Stockh.), 32,

Shepard, M. C. (1954). Amer. J. Syph., 38, 113.

Siboulet, A. (1952). J. Urol. méd. chir., 58, 408.

Thygeson, P. (1954). Paper read at the International Symposium on Non-Gonococcal Urethritis, Monaco. WHO Publication VDT/129.

Van Herick, W., and Eaton, M. D. (1945). J. Bact., 50, 47.

Etudes de l'étiologie de l'urétrite non-gonococcique et de la maladie de Reiter

Résumé

L'écoulement urétral de 17 malades atteints d'urétrite non-gonococcique et de 3 malades atteints de maladie de Reiter fut étudié dans des cultures cellulaires d'embryon 
de poulet et on y rechercha des effets cytopathiques et des inclusions. On n'observa pas d'altérations dans les cultures provenant des cas d'urétrite non-gonococcique. Dans un cas de maladie de Reiter, il se produisit une dégénération, mais on ne put pas la repasser continuellement. Dans ce cas le PPLO ("organisme du type pleuropneumonie") poussa abondamment, et le sérum de ce malade contenait des anticorps, fixant le complément, contre cet organisme. On pense que l'effet cytopathique dans les cultures de cet écoulement urétral était probablement dû au PPLO, qu'on savait présent, et non pas à un virus. Il n'y avait pas de preuves de contamination des cultures d'embryon de poulet par le PPLO venant de l'oeuf. 